\title{
Macroeconomic Uncertainty, Growth and Inflation in the Eurozone: A Causal Approach
}

Vasilios Plakandaras ${ }^{\circ}$, Rangan Gupta ${ }^{\mathrm{b}}$, Periklis Gogas ${ }^{\mathrm{a}}$ and Theophilos Papadimitriou ${ }^{\mathrm{a}}$

${ }^{a}$ Department of Economics, Democritus University of Thrace, Komotini, Greece

${ }^{\mathrm{b}}$ Department of Economics, University of Pretoria, Pretoria, South Africa

Abstract

In this paper, we evaluate the causal relationship between macroeconomic uncertainty indices, inflation and growth rate for 17 Eurozone countries on a county level examination. In performing a series of linear and non-linear causality tests we find little evidence of a causal relationship between uncertainty and macroeconomic variables. Thus, macroeconomic analysis based on uncertainty indices should be treated with caution.

JEL codes: C32, E23, E27, E31, E37

Keywords: Output growth, inflation, uncertainty, causality

\footnotetext{
* Corresponding author: vplakand@econ.duth.gr, +306944503768, University Campus, Komotini, Greece.
} 


\section{Highlights}

- Causal inference between uncertainty and economic activity is examined

- Application of a wide spectrum of linear and nonlinear causality tests

- Macroeconomic uncertainty raises inflation and lowers output only episodically

- The significance of economic uncertainty is overstated

\section{Words: 1982}




\section{Introduction}

In the aftermath of the global financial and the European debt sovereign crisis, a growing literature has resuscitated the interest on the effect of macroeconomic uncertainty on output growth and inflation. In the presence of uncertainty, policy authorities and investors are hesitant on the proper course of actions, hindering economic activity. While all previous research is focused on examining the correlation between uncertainty and economic activity, little has been done towards examining a causal relationship between the two.

In his Nobel lecture Friedman (1976) argues that high inflation uncertainty leads to higher future inflation, which is later empirically validated by Cukierman and Meltzer (1986). Later studies reach to contradicting results on a bi-directional relationship between inflation and uncertainty, mainly due to different definitions of uncertainty: in favor (Grier and Perry, 2000; Thornton, 2007; Neanidis and Savva, 2013) or against (Hartmann and Herwartz, 2012; Conrad and Karanasos, 2005). In contrast, the literature reports the existence of a causal relationship between uncertainty and output growth (among others Jurado et al., 2015).

Since uncertainty cannot be observed directly, a common approach is to measure the error in forecasting. Rossi and Sekhposyan $(2015,2017)$ state that uncertainty is associated with the likelihood of observing a certain value of the forecasting error. Taking the historical unconditional distribution of the errors, uncertainty is the quantile that the forecast error appears; if the $99^{\text {th }}$ percentile is $3 \%$ and the actual forecast error is $3 \%$ then uncertainty is high. This index adheres closely to economic fluctuations, it is easy to produce in country level and it is highly correlated with the typical indices in the literature (VSTOXX and Baker et al., 2016). In order to evaluate the connection between uncertainty and the economy, we perform a battery of linear and nonlinear causality tests between uncertainty, output growth and inflation of the Eurozone area.

\section{Causality tests}

Among a plethora of alternatives, in this paper we apply five causality tests ${ }^{1}$ as follows:

\footnotetext{
${ }^{1}$ All tests evaluate the null hypothesis that no causal relationship exists between the variables under examination.
} 
A. The Granger (1969) causality test is the cornerstone in testing causal relationships in economics. The test examines whether a variable $x$ and its lags can be used in forecasting a variable $y$ and vice versa. Given a stationary bivariate VAR model with series $x_{t}$ and $y_{t}$ :

$$
\begin{aligned}
& \Delta y_{t}=a_{11}+\sum_{i=1}^{k} \beta_{11 i} \Delta y_{t-i}+\cdots+\sum_{j=1}^{k} \beta_{12 j} \Delta x_{t-j}+\varepsilon_{12 t} \\
& \Delta x_{t}=a_{21}+\sum_{i=1}^{k} \beta_{21 i} \Delta x_{t-i}+\cdots+\sum_{j=1}^{k} \beta_{22 j} \Delta y_{t-j}+\varepsilon_{22 t}
\end{aligned}
$$

where is $k$ the maximum number of lags, $\Delta$ the difference operator, $\alpha, \beta$ coefficients for estimation and $\varepsilon$ the error term. The null hypothesis is that $H_{0}: \beta_{12 j}=0, j=1,2,3, \ldots, q$. If the null is rejected then past values of $x$ have linear predictive power on current $y$.

B. Ashley and Tsang (2014) argue that the in-sample estimation of causality can be a poor approach to out-of-sample forecasting. Thus, they propose a cross sample validation (CSV) scheme; the sample is separated into equal segments and in a repetitive process one segment is considered each time as the "unknown" sample and the rest are used for calculating the $F$-statistic. The mean value of the errors over the entire sample should provide a better predictor on the existence of a causal relationship.

C. Under a different perspective, Hiemstra and Jones (1994) propose a non-linear causality test based on the concept of correlation integral. Given an $m$-dimensional time series $x$ of length $T$, the correlation integral is:

$$
C(T, e)=\sum_{i=1}^{T-1} \sum_{j=i+1}^{T} I\left(x_{i}, x_{j}, e\right) \times \frac{2}{T(T-1)}
$$

Subject to

$$
I\left(x_{i}, x_{j}, e\right)=\left\{\begin{array}{cr}
1 & \left|x_{i}, x_{j}\right|<e \\
0 & \text { otherwise }
\end{array}\right.
$$

where $\left|x_{i}, x_{j}\right|$ is the Euclidean distance. In other words the correlation integral measures the fraction of data pairs that are within a maximum distance $e$. Examining the stationary trivariate process $\left\{x_{t}, y_{t-l_{x}}^{l_{x}}, y_{t-l_{y}}^{l_{y}}\right\}$, where $l_{x}$ and $l_{y}$ are lag orders. Then $y$ does not Granger cause $x$ if:

$$
\begin{gathered}
\operatorname{Pr}\left(\left\|x_{i}, x_{j}\right\|<e \mid\left\|x_{i-l_{x}}^{l_{x}}-x_{j-l_{x}}^{l_{x}}\right\|<e,\left\|y_{i-l_{y}}^{l_{y}}-y_{j-l_{y}}^{y}\right\|<e\right)= \\
\operatorname{Pr}\left(\left\|x_{i}, x_{j}\right\|<e\|\| x_{i-l_{x}}^{l_{x}}-x_{j-l_{x}}^{l_{x}} \|<e\right)
\end{gathered}
$$


where $\operatorname{Pr}(\circ)$ denotes probability, $i, j$ are values of the series $x_{t}, y_{t}$ and $\|\circ\|$ the maximum norm. The Granger causality condition can be rewritten using the correlation integral as

$$
H_{0}: \frac{C\left(m+l_{x}, l_{y}, e\right)}{C\left(l_{x}, l_{y}, e\right)}=\frac{C\left(m+l_{x}, e\right)}{C\left(l_{x}, e\right)}
$$

for given values of $l_{x}, l_{y}$ and $e>0$.

D. Hill (2007) builds on the aforementioned trivariate system and proposes a rolling and a recursive parametric representation of causality chains for bivariate and trivariate VAR processes. With the proposed approach it is possible to test for causality in multi-steps ahead while a bivariate and a rolling window approach is also feasible.

E. We also examine the non-parametric quantile-based methodology proposed by Jeong $e t$ al. (2012). This approach is robust to extreme values in the data and captures general nonlinear dynamic dependencies. Formally let $Z_{t}=\left(x_{t}, y_{t}\right) . \quad F_{y_{t} \mid Z_{t-1}}\left(y_{t}, Z_{t-1}\right)$ and $F_{y_{t} \mid y_{t-1}}\left(y_{t}, y_{t-1}\right)$ denote the conditional distribution functions of $y_{t}$ given $Z_{t-1}$ and $y_{t-1}$, respectively. If we denote $Q_{\theta}\left(Z_{t-1}\right)=Q_{\theta}\left(y_{t} \mid Z_{t-1}\right)$ and $Q_{\theta}\left(y_{t-1}\right)=Q_{\theta}\left(y_{t} \mid y_{t-1}\right)$ the quantiles, we have $F_{y_{t} \mid Z_{t-1}}\left\{Q_{\theta}\left(Z_{t-1}\right) \mid Z_{t-1}\right\}=\theta$ with probability one. Consequently, the causality in the $\theta^{\text {th }}$ quantile hypotheses to be tested can be specified as:

$$
\begin{gathered}
H_{0}: \operatorname{Pr}\left[F_{y_{t} \mid Z_{t-1}}\left\{Q_{\theta}\left(y_{t-1}\right) \mid Z_{t-1}\right\}=\theta\right]=1, \\
H_{1}: \operatorname{Pr}\left[F_{y_{t} \mid Z_{t-1}}\left\{Q_{\theta}\left(y_{t-1}\right) \mid Z_{t-1}\right\}=\theta\right]<1
\end{gathered}
$$

\section{Empirical results}

We compile a dataset of quarterly annualized output growth and monthly annualized inflation for 17 Eurozone countries. The quarterly and monthly uncertainty indices for output growth and inflation are from Rossi and Sekhposyan (2017). In the case of the trivariate Hill's test that builds on a trivariate VAR we also include the quarterly inflation and the monthly IPI for the causality tests on output and inflation, respectively. The descriptive statistics are reported in the Appendix. In Table 1 we report the results from all causality tests on the null hypothesis that the output uncertainty index of Rossi and Sekhposyan (2017) does not granger cause output growth. In Table 2 we report the 
respective results for the inflation and the inflation index, respectively. Due to space restrictions the details for the parameters of each test are reported in the Appendix.

As we observe from Table 1, based on all tests, we cannot reject the null hypothesis that uncertainty does not granger-cause output growth. The results from Table 2 are similar. While the linear Granger causality test rejects the null hypothesis for certain countries, the rest of the tests do not corroborate to these results. Rejections of the null hypothesis are different between tests and are only episodically. Our empirical findings do not support the notion stated by Rossi and Sekposyan (2015), that the macroeconomic uncertainty is a measure of the degree that the economy is predictable, since we do not detect a causal relationship between their indices and the macroeconomic variables. 


\begin{tabular}{|c|c|c|c|c|c|c|c|c|c|c|}
\hline \multirow[b]{2}{*}{ Country } & \multicolumn{2}{|c|}{$\begin{array}{l}\text { Linear (Granger) } \\
\text { Causality test }\end{array}$} & \multirow{2}{*}{$\begin{array}{c}\text { CSV test } \\
\begin{array}{c}\text { CSV75 } \\
\text { p-values }\end{array}\end{array}$} & \multirow{2}{*}{$\begin{array}{c}\text { Non-linear } \\
\text { HJ test } \\
\text { t-stat }\end{array}$} & \multirow{2}{*}{$\begin{array}{c}\text { Hill } \\
\text { Bivariate } \\
\text { Rejection } \\
\text { Percent } \\
\text { (Recursive) }\end{array}$} & \multicolumn{2}{|c|}{ Hill Trivariate } & \multicolumn{3}{|c|}{$\begin{array}{c}\text { Causality-in-quantiles } \\
\text { test }\end{array}$} \\
\hline & Lags & F-stat & & & & $\begin{array}{c}\text { Rejection } \\
\text { percent } \\
\text { (Rolling) }\end{array}$ & $\begin{array}{c}\text { Rejection } \\
\text { percent } \\
\text { (Recursive) }\end{array}$ & $\begin{array}{c}5 \% \\
\text { t-stat }\end{array}$ & $\begin{array}{c}\text { Median } \\
\text { t-stat }\end{array}$ & $\begin{array}{l}95 \% \\
\text { t-stat }\end{array}$ \\
\hline (1) & (2) & (3) & (4) & $(5)$ & (6) & $(7)$ & $(8)$ & (9) & (10) & (11) \\
\hline Austria & 1 & 1.39 & 0.44 & 0.67 & 0.00 & 0.00 & 0.00 & 0.10 & 0.07 & 0.13 \\
\hline Belgium & 1 & 1.28 & 0.59 & 0.96 & 0.00 & 1.92 & 0.00 & 0.04 & 0.02 & 0.00 \\
\hline Cyprus & 4 & $5.94 *$ & 0.52 & 0.53 & 26.67 & 0.00 & 0.00 & 0.00 & 0.01 & 0.04 \\
\hline Estonia & 2 & 1.62 & 0.45 & -0.33 & 21.05 & 2.56 & 0.00 & 1.60 & 1.72 & 0.14 \\
\hline Finland & 3 & 0.72 & 0.57 & -0.77 & 9.38 & 5.56 & 0.00 & 1.76 & 1.67 & 0.37 \\
\hline France & 2 & 1.36 & 0.59 & -0.71 & 0.00 & 4.16 & 0.00 & 1.30 & 1.61 & 0.44 \\
\hline Germany & 1 & $4.57 *$ & 0.59 & -1.32 & 6.25 & 1.39 & 0.00 & 0.03 & 0.01 & 0.00 \\
\hline Greece & 3 & 0.47 & 0.50 & 0.81 & 0.00 & 0.00 & 0.00 & 0.77 & 0.73 & 0.25 \\
\hline Ireland & 3 & $4.71 *$ & 0.38 & 0.37 & 86.96 & 0.00 & 2.33 & 0.67 & 0.61 & 0.29 \\
\hline Italy & 6 & 1.17 & 0.46 & 0.14 & 3.85 & 0.00 & 0.00 & $2.32 *$ & $2.41 *$ & 0.84 \\
\hline Latvia & 2 & $6.25^{*}$ & 0.47 & -0.43 & 5.26 & 0.00 & 0.00 & $3.48 *$ & $2.45^{*}$ & 0.71 \\
\hline Lithuania & 1 & 1.33 & 0.57 & -0.20 & 0.00 & 0.00 & 0.00 & 0.02 & 0.02 & 0.00 \\
\hline Portugal & 2 & 0.51 & 0.39 & 1.32 & 0.00 & 0.00 & 0.00 & 0.19 & 0.60 & 0.07 \\
\hline Slovakia & 1 & 0.09 & 0.52 & 0.95 & 0.00 & 0.00 & 0.00 & $2.09 *$ & 1.37 & 0.32 \\
\hline Slovenia & 8 & $5.07 *$ & 0.45 & -1.46 & 0.00 & 0.00 & 0.00 & 0.02 & 0.06 & 0.01 \\
\hline Spain & 9 & 2.39 & 0.51 & 0.83 & 34.38 & 0.00 & 0.00 & 0.25 & 0.44 & 0.45 \\
\hline Netherlands & 1 & $3.36^{*}$ & 0.50 & -0.54 & 7.69 & 0.00 & 0.00 & 0.28 & 0.19 & 0.22 \\
\hline
\end{tabular}

Note: $*$ denotes rejection of the null hypothesis of non-causality at the $5 \%$ level of significance. 


\begin{tabular}{|c|c|c|c|c|c|c|c|c|c|c|}
\hline \multirow[b]{2}{*}{ Country } & \multicolumn{2}{|c|}{$\begin{array}{c}\text { Linear Causality } \\
\text { test }\end{array}$} & \multirow{2}{*}{$\begin{array}{c}\text { CSV test } \\
\text { CSV75 } \\
\text { p-values }\end{array}$} & \multirow{2}{*}{$\begin{array}{c}\text { Non-linear } \\
\text { HJ test } \\
\text { t-stat }\end{array}$} & \multirow{2}{*}{$\begin{array}{c}\text { Hill } \\
\text { Bivariate } \\
\begin{array}{c}\text { Rejection } \\
\text { percent }\end{array}\end{array}$} & \multicolumn{2}{|c|}{ Hill Trivariate } & \multicolumn{3}{|c|}{$\begin{array}{l}\text { Quantile causality } \\
\text { test }\end{array}$} \\
\hline & Lags & F-stat & & & & $\begin{array}{l}\text { Rejection } \\
\text { percent } \\
\text { (Rolling) } \\
\end{array}$ & $\begin{array}{c}\text { Rejection } \\
\text { percent } \\
\text { (Recursive) }\end{array}$ & $\begin{array}{l}5 \% \\
\text { t-stat }\end{array}$ & $\begin{array}{c}\text { Median } \\
\text { t-stat }\end{array}$ & $\begin{array}{l}95 \% \\
\text { t-stat }\end{array}$ \\
\hline (1) & $(2)$ & $(3)$ & $(4)$ & $(5)$ & $(6)$ & $(7)$ & (8) & $(9)$ & (10) & $(11)$ \\
\hline Austria & 12 & 0.65 & 0.45 & -0.18 & 0.00 & 0.36 & 0.00 & 0.12 & 0.12 & 0.04 \\
\hline Belgium & 1 & 0.10 & 0.72 & 0.87 & 1.62 & 0.73 & 0.00 & 0.15 & 0.44 & 0.17 \\
\hline Cyprus & 12 & $6.65 *$ & $0.05^{*}$ & -0.28 & 4.70 & 0.00 & 0.00 & 0.21 & 0.50 & 0.48 \\
\hline Estonia & 1 & 0.76 & 0.93 & -0.93 & 0.00 & 1.71 & 0.00 & 2.03 & $3.07 *$ & 0.63 \\
\hline Finland & 15 & 0.49 & 0.82 & 0.98 & 0.54 & 0.07 & 0.00 & 0.28 & 0.61 & 0.26 \\
\hline France & 13 & 0.29 & 0.40 & 0.86 & 29.19 & 1.09 & 0.00 & 0.13 & 0.80 & 0.27 \\
\hline Germany & 12 & $7.89 *$ & 0.74 & -0.03 & 1.62 & 1.28 & 0.00 & 0.35 & 0.34 & 0.08 \\
\hline Greece & 12 & $4.64 *$ & 0.53 & 0.69 & 58.33 & 0.07 & 0.00 & 0.30 & 0.64 & 0.30 \\
\hline Ireland & 13 & 0.07 & 0.31 & 1.42 & 5.95 & 0.00 & 0.00 & 1.20 & $2.18^{*}$ & 0.71 \\
\hline Italy & 12 & 0.01 & 0.21 & 1.77 & 9.73 & 0.07 & 0.00 & 0.05 & 0.10 & 0.02 \\
\hline Latvia & 15 & 0.49 & 0.79 & 1.17 & 0.00 & 0.00 & 0.00 & 0.17 & 0.33 & 0.37 \\
\hline Lithuania & 12 & 0.80 & $0.04 *$ & 0.02 & 1.62 & 0.00 & 0.00 & 0.01 & 0.02 & 0.02 \\
\hline Portugal & 13 & 0.59 & 0.09 & 0.02 & 8.07 & 1.45 & 0.00 & 0.62 & 1.24 & 0.37 \\
\hline Slovakia & 12 & 1.24 & 0.11 & -0.05 & 4.03 & 0.00 & 0.00 & 0.01 & 0.01 & 0.00 \\
\hline Slovenia & 15 & 2.36 & 0.10 & 1.24 & 21.08 & 0.05 & 0.04 & 0.02 & 0.02 & 0.01 \\
\hline Spain & 14 & 1.91 & 0.36 & -0.17 & 15.68 & 0.04 & 0.00 & 0.12 & 0.28 & 0.03 \\
\hline Netherlands & 1 & $3.89 *$ & 0.45 & 1.64 & 0.00 & 0.07 & 0.00 & 0.66 & 0.76 & 0.24 \\
\hline
\end{tabular}

Note: $*$ denotes rejection of the null hypothesis of non-causality at the $5 \%$ level of significance 


\section{Concluding Remarks}

In this paper we examine the causal relationship between the uncertainty indices of Rossi and Sekhposyan (2017) on inflation and growth rate with the actual macroeconomic variables, for 17 Eurozone countries on the country level. In doing so we apply a combination of linear and nonlinear causality tests used in the economic literature. Our empirical findings imply the lack of a causal relationship between uncertainty indices and specific macroeconomic variables. Rejections of the null hypothesis are only episodically between the various tests, with the nonlinear Hiemstra and Jones (1994) and the trivariate Hill (2007 tests to accept the null for all countries. Thus the literature on forecasting macroeconomic conditions based on the uncertainty indices should be treated with caution. 


\section{References}

Baker, S. R., Bloom, N. and S. J. Davis (2016) Measuring Economic Policy Uncertainty. Quarterly Journal of Economics, 131(4), 1593-1636.

Conrad, C., Karanasos, M., 2005. On the inflation uncertainty hypothesis in the USA, Japan, and the UK: a dual long memory approach. Japan and the World Economy, 17, 327-343.

Cukierman, A., Meltzer, A., 1986. A theory of ambiguity, credibility, and inflation under discretion and asymmetric information. Econometrica, 54, 1099-1128.

Friedman, M., 1977. Nobel lecture: inflation and unemployment. Journal of Political Economy, 85, 451-472.

Granger, C.W.J. Investigating Causal Relations by Econometric Models and Cross-spectral Methods. Econometrica 1969, 37, 424-438.

Grier, K.B., Perry, M.J, 2000. The effects of real and nominal uncertainty on inflation and output growth: some GARCH-M evidence. Journal of Applied Econometrics. 15, $45-58$.

Hartmann, M., Herwartz, H., 2012. Causal relations between inflation and inflation uncertainty-Cross sectional evidence in favour of the Friedman-Ball hypothesis. Economics Letters, 115, 144-147.

Hiemstra, C., Jones, J.D., 1994. Testing for linear and nonlinear Granger causality in the stock price-volume relation. Journal of Finance 49, 1639-1664.

Jeong, K., Härdle, W.K., Song, S., 2012. A consistent nonparametric test for causality in quantile. Econometric Theory 28(4), 861-887.

Jurado K., Ludvigson S. and Ng S. (2015) Measuring Uncertainty. American Economic Review, 105(3), 1177-1216.

Neanidis K and Savva C. (2013) Macroeconomic uncertainty, inflation and growth: Regime-dependent effects in the G7. Journal of Macroeconomics, 35, 81-92.

Rossi, B., T. Sekhposyan (2015) Macroeconomic Uncertainty Indices Based on Nowcast and Forecast Error Distributions. American Economic Review, 105(5), 650-655.

Rossi, B., T. Sekhposyan (2017) Macroeconomic Uncertainty Indices for the Euro Area and its Individual Member Countries. Empirical Economics, forthcoming.

Thornton, J., 2007. The relationship between inflation and inflation uncertainty in emerging market economies. Southern Economic Journal, 73, 858-870. 


\section{Appendix}

\section{A. Descriptive statistics}

We compile quarterly Gross Production Index (GDP) and monthly Consumer Price Index (CPI) for Austria, Belgium, Cyprus, Estonia, Finland, France, Germany, Greece, Ireland, Italy, Latvia, Lithuania, Portugal, Slovakia, Slovenia, Spain and the Netherlands from the OECD database. Additionally, we compile the Industrial Production Index for the aforementioned 17 Eurozone countries, in order to train the trivariate VAR models. Malta and Luxenburg where not examined due to data unavailability. We compute quarterly annualized growth rate based on the formula Growthrate Gr $_{t}=400 \times$ $\left(\ln \left(G D P_{t} / G D P_{t-1}\right)\right)$ and monthly annualized inflation based on the formula Inflation I $_{t}=$ $1200 \times\left(\ln \left(C P I_{t} / C P I_{t-1}\right)\right)$

When we test the quarterly non-causal relationship between the uncertainty index and the growth rate based on the Hill's trivariate test, we include the inflation value matching the end of the quarter. Under the same approach, we include the monthly IPI in the trivariate model that examines the causal relationship between inflation and uncertainty. In table A1 we report the descriptive statistics for each series.

\begin{tabular}{|c|c|c|c|c|c|c|c|c|c|c|c|c|}
\hline \multicolumn{13}{|c|}{ Table A-1: Descriptive statistics } \\
\hline & \multicolumn{6}{|c|}{ Growth rate } & \multicolumn{6}{|c|}{ Inflation } \\
\hline & Date & Mean & $\begin{array}{c}\text { Standard } \\
\text { Deviation }\end{array}$ & Skewness & Kurtosis & $\begin{array}{c}\text { Jarque- } \\
\text { Bera test } \\
\text { (pvalue) }\end{array}$ & Date & Mean & $\begin{array}{c}\text { Standard } \\
\text { Deviation }\end{array}$ & Skewness & Kurtosis & $\begin{array}{c}\text { Jarque- } \\
\text { Bera test } \\
\text { (pvalue) }\end{array}$ \\
\hline Austria & $\begin{array}{l}\text { 1996Q1- } \\
\text { 2015Q1 }\end{array}$ & 1.76 & 2.77 & -0.73 & 3.95 & 0.01 & $\begin{array}{l}\text { 1990M01- } \\
\text { 2015M04 }\end{array}$ & 2.16 & 4.42 & 0.25 & 4.53 & 0.00 \\
\hline Belgium & $\begin{array}{l}\text { 1995Q1- } \\
\text { 2015Q1 }\end{array}$ & 1.77 & 2.22 & -1.32 & 7.82 & 0.00 & $\begin{array}{l}\text { 1990M01- } \\
\text { 2015M04 }\end{array}$ & 2.01 & 3.35 & 0.12 & 3.12 & 0.63 \\
\hline Cyprus & $\begin{array}{l}\text { 198Q1- } \\
\text { 2014Q4 }\end{array}$ & 4.35 & 7.63 & -0.67 & 6.26 & 0.00 & $\begin{array}{l}\text { 1998M05- } \\
\text { 2015M04 }\end{array}$ & 1.99 & 10.51 & -0.57 & 3.04 & 0.00 \\
\hline Estonia & $\begin{array}{l}\text { 1998Q2- } \\
\text { 2015Q1 }\end{array}$ & 3.34 & 9.15 & -1.74 & 8.51 & 0.00 & $\begin{array}{l}\text { 1998M05- } \\
\text { 2015M04 }\end{array}$ & 3.53 & 5.36 & 0.69 & 4.56 & 0.00 \\
\hline Finland & $\begin{array}{l}\text { 1990Q1- } \\
\text { 2015Q1 }\end{array}$ & 1.50 & 5.18 & -1.83 & 12.44 & 0.00 & $\begin{array}{l}\text { 1990M01- } \\
\text { 2015M04 }\end{array}$ & 1.80 & 3.89 & 0.41 & 4.44 & 0.00 \\
\hline France & $\begin{array}{l}\text { 1990Q1- } \\
\text { 2015Q1 }\end{array}$ & 1.54 & 1.98 & -1.08 & 6.64 & 0.00 & $\begin{array}{l}\text { 1990M01- } \\
\text { 2015M04 }\end{array}$ & 1.64 & 3.25 & -0.29 & 3.66 & 0.01 \\
\hline Germany & $\begin{array}{l}\text { 1990Q1- } \\
\text { 2015Q1 }\end{array}$ & 1.56 & 3.62 & -1.44 & 11.16 & 0.00 & $\begin{array}{l}\text { 1990M01- } \\
\text { 2015M04 }\end{array}$ & 1.89 & 3.97 & 0.65 & 5.56 & 0.00 \\
\hline Greece & $\begin{array}{l}\text { 1995Q2- } \\
\text { 2015Q1 }\end{array}$ & 0.83 & 6.09 & -0.93 & 4.26 & 0.00 & $\begin{array}{l}\text { 1993M06- } \\
\text { 2015M04 }\end{array}$ & 5.27 & 15.00 & 0.43 & 2.87 & 0.01 \\
\hline Ireland & $\begin{array}{l}\text { 1997Q2- } \\
\text { 2014Q4 }\end{array}$ & 4.13 & 8.57 & 0.18 & 3.21 & 0.77 & $\begin{array}{l}\text { 1990M01- } \\
\text { 2015M04 }\end{array}$ & 2.20 & 5.16 & -0.29 & 3.98 & 0.00 \\
\hline Italy & $\begin{array}{l}\text { 1990Q1- } \\
\text { 2015Q1 }\end{array}$ & 0.64 & 2.89 & -0.99 & 6.59 & 0.00 & $\begin{array}{l}\text { 1990M01- } \\
\text { 2015M04 }\end{array}$ & 2.73 & 2.49 & 0.16 & 3.91 & 0.00 \\
\hline Latvia & $\begin{array}{l}\text { 1998Q3- } \\
\text { 2015Q1 }\end{array}$ & 3.60 & 8.61 & -1.01 & 4.83 & 0.00 & $\begin{array}{l}\text { 1998M05- } \\
\text { 2015M04 }\end{array}$ & 3.84 & 7.28 & 0.51 & 4.14 & 0.00 \\
\hline
\end{tabular}




\begin{tabular}{|c|c|c|c|c|c|c|c|c|c|c|c|c|}
\hline Lithuania & $\begin{array}{l}\text { 1998Q3- } \\
\text { 2015Q1 }\end{array}$ & 3.79 & 8.95 & -4.37 & 30.09 & 0.00 & $\begin{array}{l}\text { 1998M05- } \\
\text { 2015M04 }\end{array}$ & 2.24 & 6.17 & 0.81 & 5.43 & 0.00 \\
\hline Netherlands & $\begin{array}{l}\text { 1990Q1- } \\
\text { 2015Q1 }\end{array}$ & 2.05 & 2.80 & -1.72 & 10.01 & 0.00 & $\begin{array}{l}\text { 1990M01- } \\
\text { 2015M04 }\end{array}$ & 2.16 & 5.33 & 0.17 & 2.50 & 0.10 \\
\hline Portugal & $\begin{array}{l}\text { 1995Q2- } \\
\text { 2015Q1 }\end{array}$ & 1.25 & 3.41 & -0.62 & 3.32 & 0.07 & $\begin{array}{l}\text { 1990M01- } \\
\text { 2015M04 }\end{array}$ & 3.51 & 6.11 & 0.70 & 5.61 & 0.00 \\
\hline Slovakia & $\begin{array}{l}\text { 1997Q2- } \\
\text { 2015Q1 }\end{array}$ & 3.64 & 7.48 & -1.92 & 16.98 & 0.00 & $\begin{array}{l}\text { 1995M02- } \\
\text { 2015M04 }\end{array}$ & 4.59 & 8.64 & 4.18 & 25.30 & 0.00 \\
\hline Slovenia & $\begin{array}{l}\text { 1998Q2- } \\
\text { 2014Q4 }\end{array}$ & 2.24 & 5.00 & -1.58 & 7.89 & 0.00 & $\begin{array}{l}\text { 1995M02- } \\
2015 \mathrm{M} 04\end{array}$ & 4.41 & 6.97 & -0.34 & 2.92 & 0.10 \\
\hline Spain & $\begin{array}{l}\text { 1995Q2- } \\
\text { 2015Q1 }\end{array}$ & 2.05 & 2.74 & -1.11 & 3.46 & 0.00 & $\begin{array}{l}\text { 1990M01- } \\
\text { 2015M04 }\end{array}$ & 3.00 & 5.73 & -0.42 & 4.79 & 0.00 \\
\hline
\end{tabular}

\section{B. Test optimization details}

The linear causality test of Granger (1969) are reported in columns (2) and (3) of Tables 1 and 2. The lag order of the regression models is selected according to the minimum SIC value. In column (4) we report the third-quartile cross-sample validation p-values (CSV75) for the CSV test, where Ashley and Tsang (2014) suggest that the test exhibits the highest rejection power. The t-statistics of the non-linear HJ test are reported in column (5), while in column (6) we report the rejection percent from a bivariate VAR model based on the recursive estimation of the Hill's test.

In the bivariate Hill causality test, starting from the $50 \%$ of the available observations we test recursively the null hypothesis using only the index and the output growth at the 5\% level of significance for all horizons greater than $h=0$ and count the numbers that we reject the null hypothesis as the sample expands. The rejection percentage is reported in columns (7) and (8) for the trivariate Hill's test, where we add quarterly inflation in the model. Columns (7) and (8) refer to rolling and recursive estimation for all horizons greater than $h=0$, respectively. Finally, in columns (9), (10) and (11) we report the t-statistic from the $10 \%$, the $50 \%$ and the $90 \%$ quantile of the quantiles causality test, evaluating typical (median) and the extreme (outlier) cases. The empirical implementation of causality in quantiles entails specifying three important choices: the bandwidth, the lag order, and the kernel type, respectively. In this study, a lag order of one is used on the basis of the minimum SIC. The bandwidth value is chosen by employing least squares cross-validation techniques. Finally, Gaussian-type kernels are employed. 